\title{
EFFECTS OF DEFORMATION TEMPERATURE ON THE MICROSTRUCTURE AND MECHANICAL PROPERTIES OF THE AA3003 ALUMINIUM ALLOY
}

\author{
VPLIV TEMPERATURE DEFORMACIJE NA \\ MIKROSTRUKTURO IN MEHANSKE LASTNOSTI Al \\ ZLITINE AA3003
}

\author{
Guiqing Chen ${ }^{1}$, Gaosheng $\mathrm{Fu}^{2}$, Xiaodong Lin ${ }^{3}$, Lili Song ${ }^{2}$, Chaozeng Cheng ${ }^{2}$, Tianyun Wei ${ }^{1}$ \\ ${ }^{1}$ Fujian Chuanzheng Communications College, Department of Mechanical Engineering, 112 Shoushan Road, Fuzhou 350007, China \\ ${ }^{2}$ Fuzhou University, College of Materials Science and Engineering, 2 Xueyuan Road, Fuzhou 350108, China \\ ${ }^{3}$ Fujian Chuanzheng Communications College, Department of Marine Engineering, 112 Shoushan Road, Fuzhou 350007, China \\ fugaosheng@fzu.edu.cn \\ Prejem rokopisa - received: 2018-04-03; sprejem za objavo - accepted for publication: 2018-07-20
}

doi:10.17222/mit.2018.063

The AA3003 aluminium alloy was deformed by isothermal compression in the deformation temperature range $300-500{ }^{\circ} \mathrm{C}$ at a strain rate of $0.1 \mathrm{~s}^{-1}$ with a Gleeble-1500 thermal simulator. The microstructure of the alloy was observed by OM and TEM, and the hardness was measured with a microhardness tester. The results show that the flow stress decreases with an increase of the deformation temperature. The dislocation density in the grain is large, and the polygonal structure occurs in the local area under low-temperature conditions. When the temperature reaches $400{ }^{\circ} \mathrm{C}$, the dislocation density decreases gradually, and the repetitive polygonal process occurs. The deformation mechanism is changed from dynamic recovery to dynamic recrystallization (DRX). The DRX volume fraction and grain size increase with an increase of the deformation temperature. The relationship between the micro-Vickers hardness and the DRX grain size of the alloy after hot deformation agrees with the Hall-Petch equation. At the strain rate of $0.1 \mathrm{~s}^{-1}$, the optimum temperature of hot deformation for the alloy is about $400{ }^{\circ} \mathrm{C}$.

Keywords: AA3003 aluminium alloy, hot deformation, dynamic recrystallization, grain size, micro-Vickers hardness

Al zlitino AA3003 so avtorji pričujočega članka deformirali z izotermnim stiskanjem v področju temperatur deformacije med $300{ }^{\circ} \mathrm{C}$ in $500{ }^{\circ} \mathrm{C}$ pri hitrostih deformacije $0.1 \mathrm{~s}^{-1}$ na termičnem simulatorju Gleeble-1500. Mikrostrukturo deformirane zlitine so opazovali pod optičnim (OM) in presevnim elektronskim mikroskopom (TEM) in izmerili mikrotrdoto zlitine. Rezultati raziskave so pokazali, da meja tečenja pada $\mathrm{z}$ naraščajočo temperaturo deformacije. Gostota dislokacij $\mathrm{v}$ kristalnih zrnih je velika in poligonalna struktura nastaja v lokalnih področjih pri nižjih temperaturah. Ko temperatura doseže $400{ }^{\circ} \mathrm{C}$ se gostota dislokacij postopno zmanjša in nastopi proces ponovne poligonalizacije. Mehanizem deformacije se spremeni iz dinamične poprave $\mathrm{v}$ dinamično rekristalizacijo (DRX). Volumski delež DRX in velikost zrn se povečujeta $\mathrm{z}$ poviševanjem temperature deformacije. Zveza med Vikersovo mikrotrdoto in velikostjo DRX zrn zlitine sledi Hall-Petch-evi enačbi. Pri hitrosti deformacije $0.1 \mathrm{~s}^{-1}$ so ugotovili, da je optimalna temperatura deformacije zlitine okoli $400{ }^{\circ} \mathrm{C}$.

Ključne besede: Al zlitina AA3003, vroča deformacija, dinamična rekristalizacija, velikost zrn, mikrotrdota po Vickersu

\section{INTRODUCTION}

One of the aims of thermoplastic deformation for aluminium alloys is DRX, which facilitates fine-grain microstructures and a performance in accordance with requirements. ${ }^{1}$ When the alloy enters the steady-state deformation stage, the orientation difference of the sub-grains and the sub-grain size are kept constant, i.e., the sub-grain structure is kept constant. During this time the DRX structure of the alloy does not change with the increase of the deformation, and it is influenced mainly by the deformation temperature and the strain rate. ${ }^{2-4}$ After the high-temperature compression deformation, the structure has changed. The structure experiences work hardening, dynamic softening and dislocation configuration changes, which will all affect the performance of the alloy. ${ }^{5}$ The DRX process has become the focus of many researchers in studying the high-temperature deformation behaviour of metals and alloys. Yang dis- covered that DRX and the coarsening of dynamic precipitation might be responsible for the continuous flow-softening behaviour by studying the 6A82 aluminium alloy. ${ }^{6}$ The effect of the deformation temperature on the microstructural evolution of the $6082 \mathrm{Al}$ alloy was studied by Kumar. ${ }^{7}$ According to a previous study of the research group, the thermal deformation constitutive equation for the AA3003 aluminium alloy has been established and it is found that the deformation conditions have a great influence on the microstructure and the properties of the alloy. ${ }^{8}$ The optimum strain rate of the alloy is $0.1 \mathrm{~s}^{-1}$, and the deformation temperature plays a key role in the final forming performance of the alloy. ${ }^{9}$ Recrystallization is a process that requires heat activation. As the deformation temperature increases, the deformation storage energy in the sample is released more during recrystallization, which increases the recrystallization driving force and increases the 
nucleation rate, resulting in enhanced recrystallization. Therefore, it is of great practical significance to study the effect of the hot-deformation temperature on the microstructure and the properties of the AA3003 aluminium alloy. A thermal simulation experiment was used to reveal the high-temperature deformation mechanism of the alloy, and build the intrinsic relationship between the deformation temperature and the DRX grain size and performance, which provides a reference for the rational selection of the thermoforming process parameters.

\section{EXPERIMENTAL PART}

The experimental material was the AA3003 aluminium alloy with a chemical composition given in Table 1. The material used was heat treated at $510{ }^{\circ} \mathrm{C}$ for $20 \mathrm{~h}$. Cylindrical specimens of $10 \mathrm{~mm}$ in diameter and $15 \mathrm{~mm}$ in length were machined for the hot-compression tests. The specimens were mounted on a Gleeble-1500 thermal simulator for an isothermal constant-strain-rate hot-compression test. The experimental conditions for the hot deformation were: heating rate of the sample controlled at $10{ }^{\circ} \mathrm{C} / \mathrm{s}$, then insulation for $5 \mathrm{~min}$ after reaching the set temperature. The constant strain rate compression was then performed. The amount of compression deformation was controlled at 0.7 . The water cooling was performed immediately after compression deformation. The deformation temperature was in the range $300-500{ }^{\circ} \mathrm{C}$ at a strain rate of $0.1 \mathrm{~s}^{-1}$. The microstructure characterization of the deformed samples was observed using an XJG-05 optical microscope (OM) and a JEM-2100F transmission electron microscope (TEM). The grain size was measured using the linear-intercept method. The microhardness of the deformed sample was tested. The load was $0.49 \mathrm{~N}$, and the load holding time was $30 \mathrm{~s}$. The microhardness of the sample was averaged after 5 points were tested for each sample.

Table 1: Chemical composition of the AA3003 aluminium alloy, in mass fractions, $(w / \%)$

\begin{tabular}{|c|c|c|c|c|c|c|c|c|c|}
\hline & $\mathrm{Fe}$ & $\mathrm{Si}$ & $\mathrm{Mn}$ & $\mathrm{Cu}$ & $\mathrm{Ti}$ & $\mathrm{Mg}$ & $\mathrm{Ni}$ & $\mathrm{Zn}$ & $\mathrm{Al}$ \\
\hline AA3003 & 0.62 & 0.58 & 1.09 & 0.068 & 0.006 & 0.03 & 0.007 & 0.008 & $\begin{array}{c}\text { bal- } \\
\text { ance }\end{array}$ \\
\hline
\end{tabular}

\section{RESULTS AND DISCUSSION}

\subsection{Flow-stress curve}

The true-stress vs. true-strain curve of the AA3003 aluminium alloy deformed at a strain rate of $0.1 \mathrm{~s}^{-1}$ and a deformation temperature of $300-500{ }^{\circ} \mathrm{C}$ is shown in Figure 1. Table 2 shows the yield stress under different deformation conditions. It is clear that the true-stress vs. true-strain curves are almost straight before the strain reaches the peak strain, and the slope is large. During this time the alloy is mainly in the micro-deformation and dynamic-recovery stage. When the strain reaches a certain degree, the flow stress increases rapidly to a

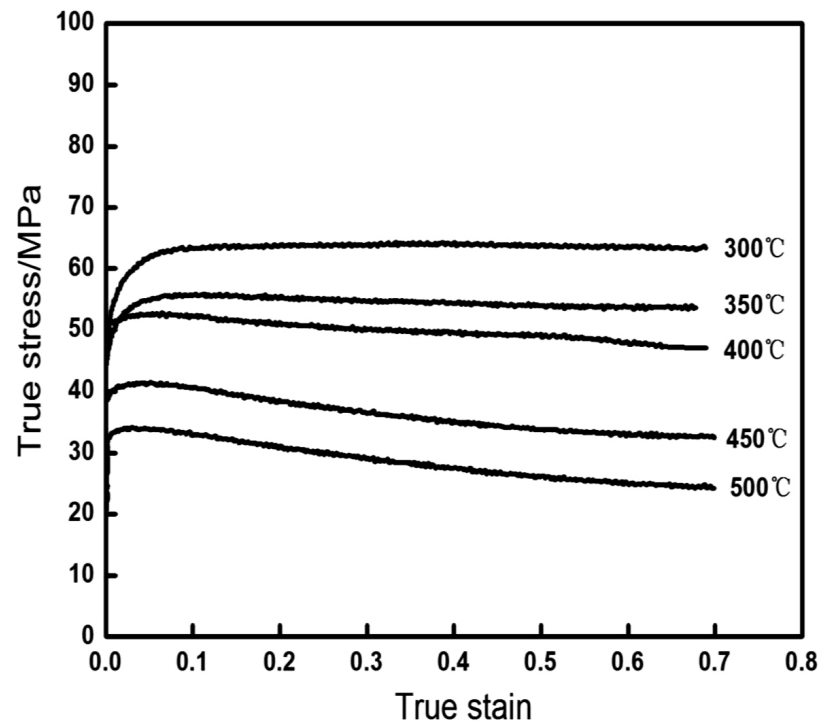

Figure 1: True-stress vs. true-strain curves of AA3003 aluminium alloy deformed at $0.1 \mathrm{~s}^{-1}$

peak. With a further increase in the strain, the flow stress decreases gradually, i.e., the flow-softening phenomenon occurs. With an increase of the strain, the flow stress tends to be in a relatively stable state. This is due to the results of the balance achieved by the work hardening and the dynamic softening in the plastic deformation process..$^{10}$ At this time, the essence of the alloy deformation is the dynamic balance achieved by proliferation, offsetting the annihilation and reorganization of the dislocations.

Table 2: Yield stress of the alloy deformed at $0.1 \mathrm{~s}^{-1}$

\begin{tabular}{|c|c|c|c|c|c|}
\hline Temperature $^{\circ} \mathrm{C}$ & 300 & 350 & 400 & 450 & 500 \\
\hline Yield stress/MPa & 62.3 & 54.5 & 51.2 & 39.8 & 34.3 \\
\hline
\end{tabular}

At the same strain rate, the flow stress decreases with the increase of the deformation temperature. The increase of the deformation temperature leads to a decrease of the critical slitting stress caused by the crystal slip, because the slip resistance originates from the binding force among the metal crystal atoms. The kinetic energy of the atom increases with the increases of the temperature, so that the binding force among the atoms decreases, i.e., the shear stress is reduced, which reduces the interplanar slip and the obstruction of the dislocation's movement, so the flow stress of the material decreases gradually in the process of hot deformation. For different slip systems, the increase in the deformation temperature leads to a difference of the decrease rates in the critical shear stress, so there may be a new slip system at high temperatures. The grain-boundary shear resistance significantly reduced with the increase of the temperature, so that the grain boundary slides easily, resulting in a deformation resistance decrease. ${ }^{11,12}$ At the same time, as the deformation temperature increases, the nucleation rate and the growth rate of the 
DRX of the alloy increase, resulting in an enhanced DRX softening effect. The nucleation of DRX is controlled by the hot-activation process. When the temperature rises, the difference between the free energy of the new phase and the free energy of the parent phase will increase, thus increasing the nucleation rate. At the same time, the driving force of the nucleus growth increases with the increase of the temperature. With the increasing deformation temperature, the dynamic recovery and the DRX are more likely to occur, so that the dislocation density can be reduced, which can offset the work hardening caused by the plastic deformation process, so that the flow stress of the hot deformation decreases.

\subsection{Effect of the Deformation Temperature on the Microstructure}

Figure 2 shows TEM microstructures of the AA3003 aluminium alloy at a strain rate of $0.1 \mathrm{~s}^{-1}$. It is clear that most of the microstructure is deformed at $300{ }^{\circ} \mathrm{C}$, as shown in Figure 2a. At this time, the dislocation density of the crystal is large, and a dislocation cell is formed by a high-density dislocation accumulation. The polygonal structure occurs in the local area, and the alloy mainly undergoes dynamic recovery to form a typical sub-grain structure. ${ }^{13-15}$ This is due to the fact that there is a dynamic balance between the dislocation propagation caused by the strain hardening and the dislocation cancellation and recombination caused by the recovery softening, resulting in a relatively stable sub-grain structure. The sub-grain exhibits a slightly elongated feature, and its extension is perpendicular to the direction of the compression axis.

When the deformation temperature increases to $400{ }^{\circ} \mathrm{C}$, as shown in Figure $\mathbf{2 b}$, equiaxed or nearly equiaxed sub-grains are formed, and the sub-grain boundary is relatively straight and clear, indicating that the dynamic recovery process has basically been completed. With the increase of the deformation temperature, the diffusion capacity of the atomic migration is enhanced, the climbing ability of the screw dislocation is also increased, and a lot of vacancies are produced by the strain, which promote the dislocation disintegration and reorganization to be more thorough and perfect. ${ }^{16}$ The moving distance of the dislocation increases, the dislocation density gradually decreases, and the repeated polygonal process occurs, which make the grain boundary clear and sharp, and cause some of the sub-grains with the same orientation to combine and grow, thus forming a larger size, and a more complete sub-grain structure. ${ }^{17}$

When the deformation temperature increases to $500{ }^{\circ} \mathrm{C}$, the interplanetary dislocation density is further reduced, and the size of the merged sub-grain increases. Through the merging and growth of the sub-grains or strain-induced grain-boundary migration, DRX occurs, as shown in Figure 2c.

It is clear from the above analysis that under the conditions of the same deformation degree and strain rate, the sub-grain size of the alloy increases with an increase of the deformation temperature. According to the theory of metal plastic deformation hot activation, when the alloy enters the steady-state rheological stage, the softening is achieved mainly through the slip of the screw-type dislocation and the climb of the edge dislocation. With the increase of the deformation temperature, the atomic hot-activation ability is enhanced, and the number of hot activations in the atomic unit strain increase. The climb can occur quickly due to the large number of vacancies produced by the strain, so the mutual cancellation and reorganization of the dislocations are more thorough, and the movable distance of the dislocation is also increased. Since the movable dislocation accelerates the motion of the sub-grain boundary, the activity of the sub-grain boundary is enhanced, leading to the growth of the sub-grain boundary. ${ }^{18,19}$ Therefore, with the increase of deformation temperature, the activity of the sub-grain boundary is further enhanced, and the sub-grain growth is intensified, causing a sub-grain size with an increasing trend.
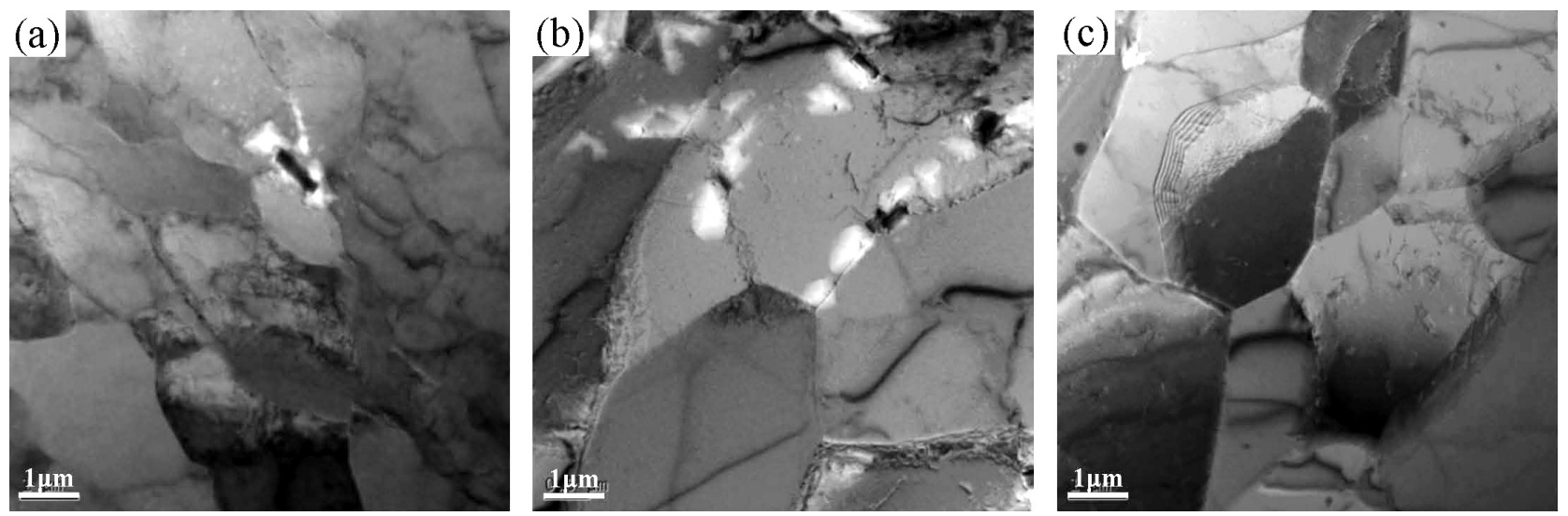

Figure 2: TEM images of AA3003 aluminium alloy deformed at $0.1 \mathrm{~s}^{-1}$ : a) $300{ }^{\circ} \mathrm{C}$, b) $400{ }^{\circ} \mathrm{C}$, c) $500{ }^{\circ} \mathrm{C}$ 


\subsection{Relationship between the Deformation Tempera- ture and the DRX Grain Size}

The grain structure of the AA3003 aluminium alloy with the changes of the deformation temperature at a strain rate of $0.1 \mathrm{~s}^{-1}$ is shown in Figure 3. It is clear that the structure is mainly composed of large deformed grains when the deformation temperature is low $\left(\leq 300{ }^{\circ} \mathrm{C}\right)$. The grain is elongated in the direction of deformation, and a small amount of recrystallized grains appear around the large grains. At this time, it is mainly the structure of the dynamic recovery. When the temperature rises to $400{ }^{\circ} \mathrm{C}$, the grain shape is uniform and fine, the original large grain is basically replaced by fine recrystallized grains, and the structure is in a more stable state, as shown in Figure 3c. When the deformation temperature is $500{ }^{\circ} \mathrm{C}$, the recrystallized grains will gradually grow, so that the whole structure shows a coarsening trend, as shown in Figure 3e.

According to Figure 3, the average grain size was measured using the linear-intercept method. The grain size of the alloy deformed under different hot-deformation conditions can be obtained as shown in Table 3. It is clear that the grain size decreases with the temperature increase, indicating that the DRX process proceeds faster as the temperature increases. Recrystallization is a process that requires hot activation. ${ }^{20-22}$ With the increase of the deformation temperature, the deformation storage energy in the sample is released more effectively in the recrystallization. It makes the crystallization driving

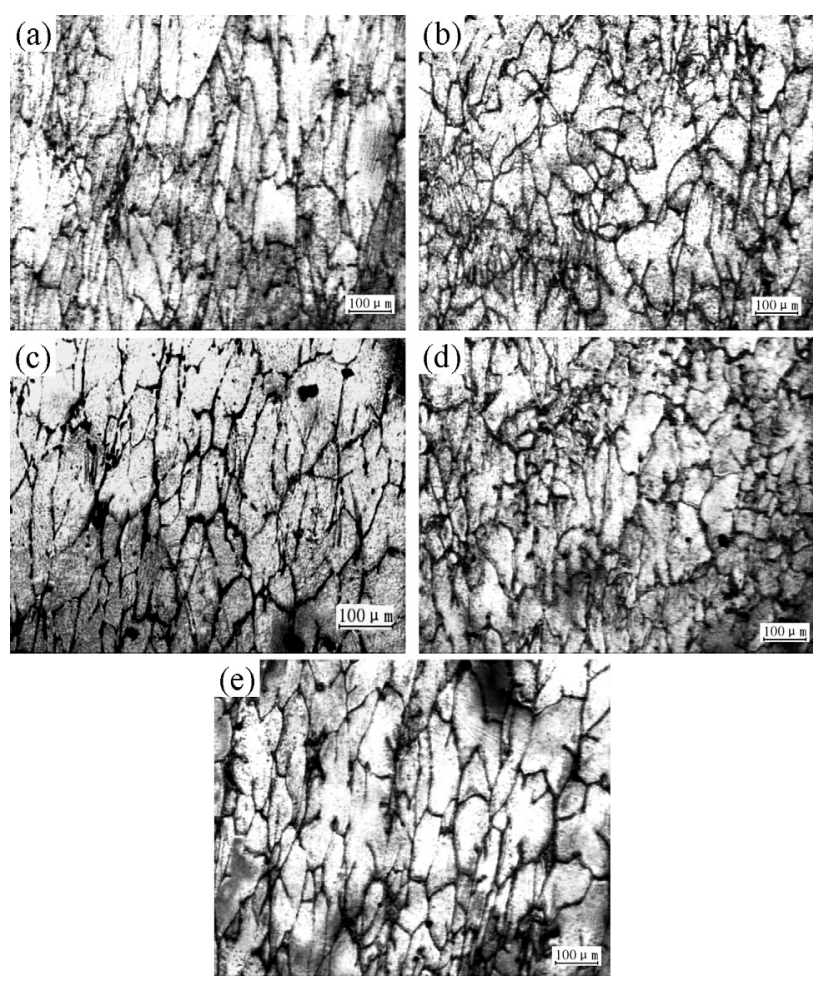

Figure 3: $\mathrm{OM}$ images of the AA3003 aluminium alloy deformed at $0.1 \mathrm{~s}^{-1}$ : a) $T=300{ }^{\circ} \mathrm{C}$, b) $T=350{ }^{\circ} \mathrm{C}$, c) $T=400{ }^{\circ} \mathrm{C}$, d) $T=450{ }^{\circ} \mathrm{C}$, e) $T=500^{\circ} \mathrm{C}$ force increase, and the nucleation rate is increased, resulting in the recrystallization being enhanced. When the deformation temperature exceeds $400{ }^{\circ} \mathrm{C}$, the recrystallization grain appears to grow. Therefore, the DRX structure obtained by deformation in the vicinity of the strain rate of $0.1 \mathrm{~s}^{-1}$ and the deformation temperature of $400{ }^{\circ} \mathrm{C}$ is preferable in view of the microstructure observation shown in Figure $\mathbf{2 b}$ and Figure 3c.

Table 3: Average grain size of the alloy deformed at $0.1 \mathrm{~s}^{-1}$

\begin{tabular}{|c|c|c|c|c|c|}
\hline Temperature $/{ }^{\circ} \mathrm{C}$ & 300 & 350 & 400 & 450 & 500 \\
\hline Grain size $/ \mu \mathrm{m}$ & 17.8 & 20.5 & 24.3 & 28.7 & 29.6 \\
\hline
\end{tabular}

\subsection{Calculation of the DRX Volume Fraction}

To establish a DRX kinematic model, the DRX volume fraction must be measured first. According to the traditional measurement involving the metallographic method, the result will inevitably be subject to metallographic corrosion and field selection. The DRX volume fraction is calculated from the eigenvalues of the flow-stress curve during the hot deformation. ${ }^{23,24}$

$$
X_{\mathrm{d}}=\frac{\sigma_{\mathrm{REC}}-\sigma_{\mathrm{DRX}}}{\sigma_{\mathrm{REC}}-\sigma_{s}}
$$

where $X_{\mathrm{d}}$ is the DRX volume fraction, $\sigma_{\mathrm{REC}}$ is the stress value on the flow-stress curve when the metal does not undergo dynamic softening, $\sigma_{\mathrm{DRX}}$ is the stress value on the high-temperature flow-stress curve, and $\sigma_{\mathrm{s}}$ is the steady stress value of the high-temperature flow-stress curve. The meaning of the symbols in Equation (1) is shown in Figure 4. According to the experimental data of thermodynamics, the actual flow stress and the DRX steady flow stress can be obtained. The dynamic recovery curve of the alloy can be obtained by nonlinear least-squares fitting and extrapolation based on the data

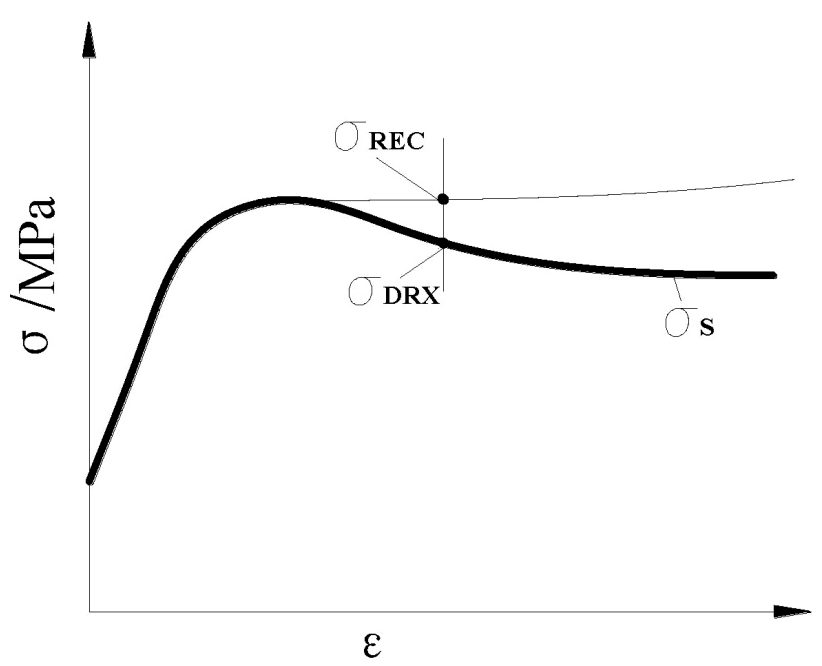

Figure 4: Illustration of the DRX volume fraction of metallic materials 


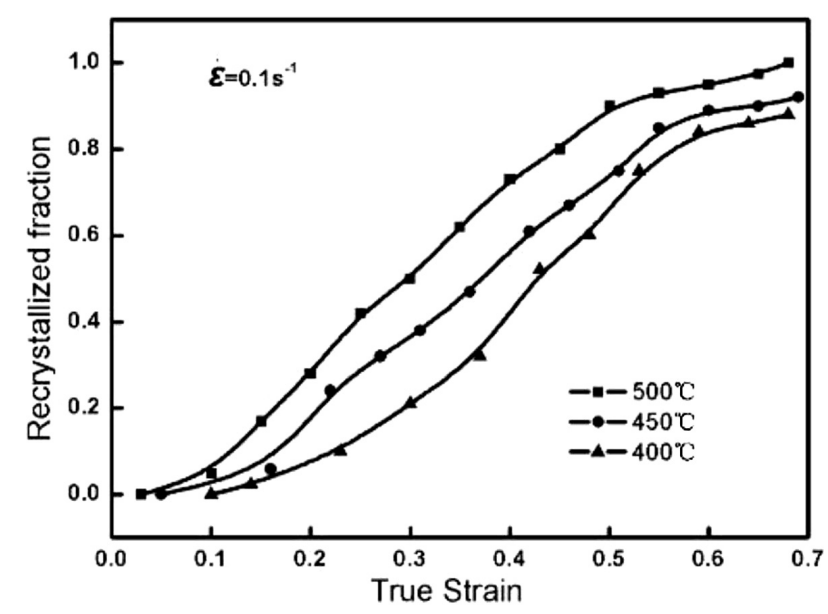

Figure 5: Relationship between recrystallized fraction and true strain deformed at $0.1 \mathrm{~s}^{-1}$

of the flow-stress curve before DRX. The fitting mathematical model is: ${ }^{24,25}$

$$
\frac{\sigma-\sigma_{0.2}}{\sigma_{\mathrm{ss}}-\sigma_{0.2}}=\left(1-e^{-\mathrm{c \varepsilon}}\right)^{\mathrm{M}}
$$

where $\sigma_{\mathrm{ss}}$ is the steady-state stress value on the dynamic recovery flow-stress curve, and $C$ and $M$ are constant coefficients.

Combining Equations (1) and (2) with the experimental data of Figure 1, the DRX volume fraction under different deformation conditions can be calculated, and the relationship curve between the DRX volume fraction and the deformation amount are plotted (Figure 5). It is clear that in the same amount of deformation, the DRX volume fraction increases with the increase of the deformation temperature. This is because the $\mathrm{Z}$ (Zener-Holloman) value decreases with an increase of the deformation temperature ${ }^{8}$ then the critical strain value of the DRX decreases, ${ }^{25}$ resulting in the DRX being more likely to occur. In addition, the grain-boundary migration ability is enhanced with the increasing deformation temperature, so that the nucleation rate of the recrystallization increased, and the DRX was carried out more fully.

\subsection{Effect of the Deformation Temperature on the Micro-Vickers Hardness}

The micro-Vickers hardness of the alloy deformed under different conditions is shown in Table 4. It can be seen that micro-Vickers hardness decreased with the increases of the deformation temperature, which relates to the occurrence of only a small amount of DRX at the low temperature. At the deformation temperature of $450{ }^{\circ} \mathrm{C}$ and $500{ }^{\circ} \mathrm{C}$, the micro-Vickers hardness changes little, indicating that their deformation mechanisms are similar. Under high-temperature conditions, the DRX is carried out more fully, and some of the grains begin to grow, leading to a slight change in the micro-Vickers hardness.

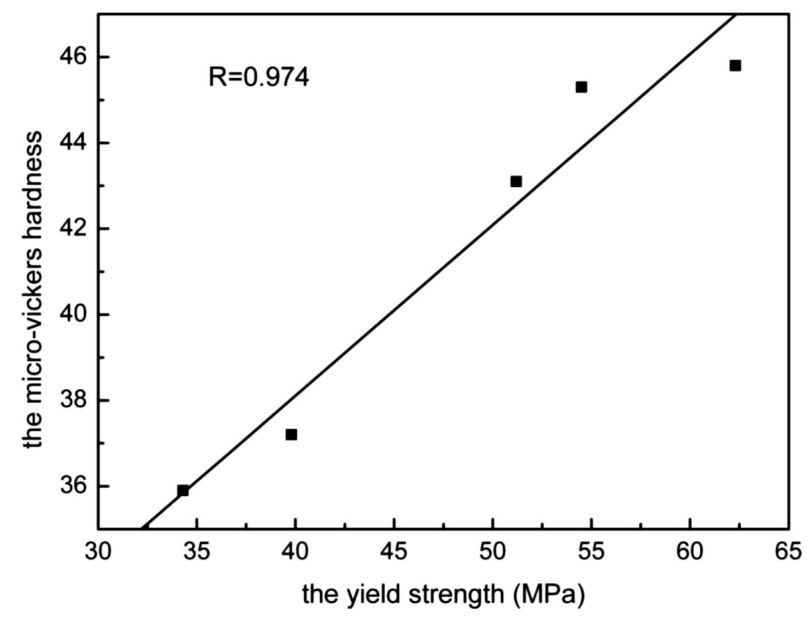

Figure 6: Curve of the micro-Vickers hardness and the yield strength

Table 4: Micro-Vickers hardness of the alloy deformed at $0.1 \mathrm{~s}^{-1}$

\begin{tabular}{|c|c|c|c|c|c|}
\hline Temperature $/{ }^{\circ} \mathrm{C}$ & 300 & 350 & 400 & 450 & 500 \\
\hline Micro-Vickers hardness/ $\mu \mathrm{m}$ & 45.8 & 45.3 & 43.1 & 37.2 & 35.9 \\
\hline
\end{tabular}

According to the data in Table 3 with Table 4 , the relationship between the micro-Vickers hardness $(H V)$ and the yield strength $\left(\sigma_{\mathrm{y}}\right)$ of the alloy can be obtained (Figure 6). There is a positive linear relationship between the micro-Vickers hardness and the yield strength: ${ }^{26}$

$$
H V=22.190+0.398 \sigma_{y}
$$

The effect of the grain size $(d)$ on the yield strength $\left(\sigma_{\mathrm{y}}\right)$ can be expressed using the Hall-Petch equation (Figure 7$): 27$

$$
\sigma_{y}=-50.96+481.84 \frac{1}{\sqrt{d}}
$$

It is clear from Equations (3) and (4) that the smaller the average grain size, the higher the micro-Vickers hardness. Therefore, the relationship between the micro-

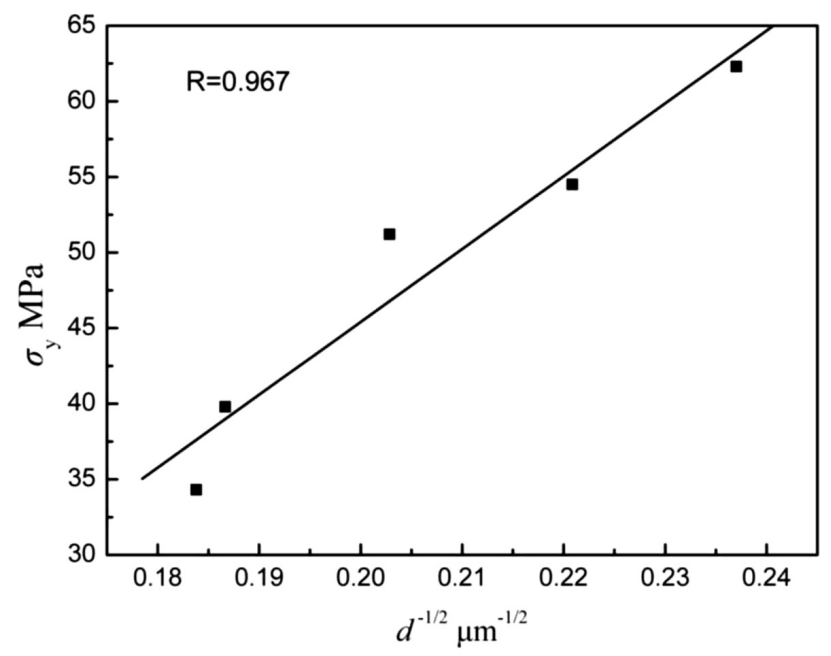

Figure 7: Curve of the grain size and the yield strength 
Vickers hardness and the grain size also agrees with the Hall-Petch equation.

\section{CONCLUSIONS}

(1) At the same strain rate, the flow stress of the AA3003 aluminium alloy decreases with the increase of the deformation temperature. When the strain reaches a certain degree, the flow stress increases rapidly to a peak value. With a further increase of the strain, the flow stress decreases gradually, i.e., the flow-softening phenomenon occurs.

(2) Under the condition of low temperature, the AA3003 aluminium alloy is mainly composed of a subgrain structure, and dynamic recovery occurs at this time. When the temperature reaches $400{ }^{\circ} \mathrm{C}$, the dislocation density decreases gradually, resulting in a repeated polygonal process and the occurrence of DRX. For the same amount of deformation, the DRX volume fraction increases as the deformation temperature increases.

(3) The higher the deformation temperature, the faster the recrystallization process. The DRX grain size increases with the increasing deformation temperature. When the deformation temperature exceeds $400{ }^{\circ} \mathrm{C}$, the recrystallization grain begins to grow. The micro-Vickers hardness after hot deformation decreases with the increase of the deformation temperature, which is in accordance with the Hall-Petch equation. The ideal structure and performance can be obtained at a strain rate of $0.1 \mathrm{~s}^{-1}$ and a deformation temperature of $400{ }^{\circ} \mathrm{C}$.

\section{Acknowledgments}

The authors would like to acknowledge the financial support of the Fujian Natural Science Foundation (2017J01156, 2017J01083), Science and Technology Project of Fujian Education Department (JA15659), Transportation science and technology project of Fujian Province (201831), and the materials nearly net forming and digital manufacturing technology service team of Fujian Chuanzheng Communications College of China.

\section{REFERENCES}

${ }^{1}$ C. Shi, X. G. Chen, Hot workability and processing maps of 7150 aluminum alloys with $\mathrm{Zr}$ and $\mathrm{V}$ additions, J. Mater. Eng. Perform., 24 (2015), 2126-2139, doi:10.1007/s11665-015-1478-1

${ }^{2}$ X. M. Chen, Y. C. Lin, D. X. Wen, J. L. Zhang, M. He, Dynamic recrystallization behavior of a typical nickel-based superalloy during hot deformation, Mater. Des., 57 (2014), 568-577, doi:10.1016/ j.matdes.2013.12.072

${ }^{3}$ T. Sakai, A. Belyakov, R. Kaibyshev, H. Miura, J. J. Jonas, Dynamic and post-dynamic recrystallization under hot, cold and severe plastic deformation conditions, Prog. Mater. Sci., 60 (2014), 130-207, doi:10.1016/j.pmatsci.2013.09.002

${ }^{4}$ G. Chen, G. Fu, H. Chen, W. Yan, C. Cheng, Z. Zou, Comparative study of the influence of various melt-treatment methods on hot deformation behavior of $3003 \mathrm{Al}$ alloy, Met. Mater. Int., 18 (2012) 1, 129-134, doi:10.1007/s12540-012-0015-0

${ }^{5}$ K. A. Babu, S. Mandal, A. Kumar, C. N. Athreya, B. D. Boer, V. S. Sarma, Characterization of hot deformation behavior of alloy 617 through kinetic analysis, dynamic material modeling and microstructural studies, Mater. Sci. Eng. A, 664 (2016), 177-187, doi:10.1016/j.msea.2016.04.004

${ }^{6}$ Q.Yang, D. Yang, Z. Zhang, L. Cao, X. Wu, G. Huang, Q. Liu, Flow behavior and microstructure evolution of 6A82 aluminium alloy with high copper content during hot compression deformation at elevated temperatures, T. Nonferr. Metal. Soc., 26 (2016) 3, 649-657, doi:10.1016/S1003-6326(16)64154-7

${ }^{7}$ N. Kumar, R. Jayaganthan, H. G. Brokmeier, Effect of deformation temperature on precipitation, microstructural evolution, mechanical and corrosion behavior of $6082 \mathrm{Al}$ alloy, T. Nonferr. Metal. Soc., 27 (2017) 3, 475-492, doi:10.1016/S1003-6326(17)60055-4

${ }^{8}$ G. Chen, G. Fu, S. Lin, C. Cheng, W. Yan, H. Chen, Simulation of flow of 3003 aluminum alloy under hot compressive deformation, Met. Sci. Heat Treat., 54 (2013) 11-12, 623-627, doi:10.1007/ s11041-013-9560-5

${ }^{9}$ G. Chen, G. Fu, H. Chen, C. Cheng, W. Yan, S. Lin, Optimization of a hot deformation process of the 3003 aluminum alloy by processing maps, Met. Mater. Int., 18 (2012) 5, 813-819, doi:10.1007/s12540012-5010-y

${ }^{10}$ G. M. Rusakov, A. G. Illarionov, Yu. N. Loginov, M. L. Lobanov, A. A. Redikul'tsev, Interrelation of crystallographic orientations of grains in aluminum alloy amg6 under hot deformation and recrystallization, Met. Sci. Heat Treat., 56 (2015), 650-655, doi:10.1007/ s11041-015-9816-3

${ }^{11}$ E. T. Park, B. E. Lee, D. S. Kang, J. Kim, B. S. Kang, W. J. Song, Analytical prediction of flow stress on aluminum alloy/self-reinforced polypropylene laminated sheet material considering temperature-dependent material constants, Int. J. Precis. Eng. Manuf., 17 (2016), 487-493, doi:10.1007/s12541-016-0061-5

${ }^{12}$ G. Chen, G. Fu, T. Wei, C. Cheng, H. Wang, J. Wang, Effect of initial grain size on the dynamic recrystallization of hot deformation for 3003 aluminum alloy, Met. Mater. Int., 24 (2018) 4, 711-719, doi:10.1007/s12540-018-0093-8

${ }^{13}$ G. M. Rusakov, A. G. Illarionov, Yu. N. Loginov, M. L. Lobanov, A. A. Redikul'tsev, Interrelation of crystallographic orientations of grains in aluminum alloy amg6 under hot deformation and recrystallization, Met. Sci. Heat Treat., 56 (2015), 650-655, doi:10.1007/s11041-015-9816-3

${ }^{14}$ G. E. Kodzhaspirov, M. I. Terent'ev, S. A. Filippov, Effect of hot deformation parameters on austenitic Ni-Co-Cr-Mo-alloy microstructure evolution, Met. Sci. Heat Treat., 56 (2014), 239-244, doi:10.1007/s11041-014-9739-4

${ }^{15}$ M. E. Wahabi, L. Gavard, F. Montheillet, J. M. Cabrera, J. M. Prado, Effect of initial grain size on dynamic recrystallization in high purity austenitic stainless steels, Acta. Mater., 53 (2005), 4605-4612, doi:10.1016/j.actamat.2005.06.020

${ }^{16}$ G. Chen, G. Fu, T. Wei, C. Cheng, J. Wang, H. Wang, Establishment of dynamic-recrystallization-state diagram of hot deformation for 3003 aluminum alloy, Mater. Tehnol., 52 (2018) 3, 341-347, doi:10.17222/mit.2017.176

${ }^{17}$ G. Chen, G. Fu, T. Wei, C. Cheng, S. Lin, L. Song, Effect of melt treatment on microstructure and mechanical properties of AA3003 aluminum alloy, Mater. Tehnol., 52 (2018) 5, 583-599, doi:10.17222/ mit.2017.207

${ }^{18}$ H. R. Rezaei Ashtiani, M. H. Parsa, H. Bisadi, Effects of initial grain size on hot deformation behavior of commercial pure aluminum, Mater. Des., 42 (2012), 478-485, doi:10.1016/j.matdes.2012.06.021

${ }^{19}$ B. Verlinden, A. Suhadi, L. Delaey, A generalized constitutive equation for an aa6060 aluminium alloy, Scripta Metall. Mater., 28 (1993), 1441-1446, doi:10.1016/0956-716X(93)90496-F 


\section{G. CHEN et al.: EFFECTS OF DEFORMATION TEMPERATURE ON THE MICROSTRUCTURE AND MECHANICAL ...}

${ }^{20}$ G. Ji, F. Qin, L. Zhu, Q. Li, L. Li, Dynamic recrystallization kinetics of cu-0.36cr-0.03zr alloy during hot compression, J. Mater. Eng. Perform., 26 (2017), 2698-2707, doi:10.1007/s11665-017-2701-Z

${ }^{21}$ G. Z. Quan, G. C. Luo, J. T. Liang, D. S. Wu, A. Mao, Q. Liu, Modelling for the dynamic recrystallization evolution of ti-6al-4v alloy in two-phase temperature range and a wide strain rate range, Comp. Mater. Sc., 97 (2015), 136-147, doi:10.1016/j.commatsci. 2014.10.009

${ }^{22}$ H. Mirzadeh, M. Roostaei, M. H. Parsa, R. Mahmudi, Rate controlling mechanisms during hot deformation of $\mathrm{mg}-3 \mathrm{gd}-1 \mathrm{zn}$ magnesium alloy: dislocation glide and climb, dynamic recrystallization, and mechanical twinning, Mater. Des., 68 (2015), 228-231, doi:10.1016/j.matdes.2014.12.020

${ }^{23}$ J. C. Tan, M. J. Tan, Dynamic continuous recrystallization characteristics in two stage deformation of $\mathrm{Mg}-3 \mathrm{Al}-1 \mathrm{Zn}$ alloy sheet, Mater.
Sci. Eng. A, 339 (2003), 124-134, doi:10.1016/S0921-5093(02) 00096-5

${ }^{24}$ M. E. Kassner, M. M. Myshlyaev, H. J. McQueen, Large-strain torsional deformation in aluminum at elevated temperatures, Mater. Sci. Eng. A, 108 (1989), 45-61, doi:10.1016/0921-5093(89)90405-X

${ }^{25}$ G. Chen, G. Fu, W. Yan, C. Cheng, Z. Zou, Mathematical model of dynamic recrystallization of aluminum alloy 3003, Met. Sci. Heat Treat., 55 (2013), 220-225, doi:10.1007/s11041-013-9609-5

${ }^{26}$ J. T. Busby, M. C. Harsh, G. S. Was ,The relationship between hardness and yield stress in irradiated austenitic and ferritic steels, J. Nucl. Mater., 336 (2005), 267-278, doi:10.1016/j.jnucmat.2004. 09.024

${ }^{27}$ T. Nagasaka, H. Yoshida, K. Fukumoto, T. Yamamoto, H. Matsui, Mechanical properties of a high-purity fe-9cr-2w-0.1c model alloy for low-activation ferritic steels for fusion reactors, Mater. Trans. JIM, 41 (2000), 170-177, doi:10.2320/matertrans1989.41.170 